\title{
Intermestic Security Challenges: Managing Transnational Bonds
}

\author{
Jörg Friedrichs, Associate Professor, \\ Department of International Development, University of Oxford
}

Accepted for publication by European Journal of International Security on 31 October 2017

\begin{abstract}
Intermestic security challenges arise when there is concern in a country that a dissatisfied minority relies on transnational bonds with a foreign kin-group for support. They result from ethnic and/or ideological affinities translating into foreign support seen as problematic, and they are aggravated when the dissatisfied minority is able to raise territorial claims. This can lead to complications not only in domestic politics but also in international relations (hence, the term 'intermestic'). Intermestic challenges can escalate into civil war and other political calamities, but they can also be managed by governments. This article develops a theoretical model and discusses it with regard to China and its Muslim-majority neighboring countries. To the west of China, transnational bonds of Uyghur Muslims in Xinjiang with co-ethnics and coreligionists in Central Asia, Pakistan, and Afghanistan complicate Chinese relations with those countries. In the southeast, transnational bonds of ethnic Chinese in Indonesia and Malaysia with their ancestral homeland have complicated Indonesian and Malaysian relations with China. While the cases have followed different trajectories, Beijing has managed either challenge rather successfully. The theoretical model developed and the management strategies discussed are likely to be useful in other contexts.
\end{abstract}

Keywords: Intermestic relations, transnational relations, ethnicity, ideology, diaspora

Correspondence to: Jörg Friedrichs, University of Oxford, Department of International Development, 3 Mansfield Rd, Oxford OX1 3TB, England. Author’s email: joerg.friedrichs@qeh.ox.ac.uk

Acknowledgments: Thanks to Raphael Bradenbrink, Nathan Brown, John Gledhill, Kevin Fogg, Elaine Ho, Sean Lynn-Jones, and Rinku Lamba for helpful comments and suggestions. Thanks also to the anonymous reviewers who have helped to make this a better article.

\section{Biographical information}

Jörg Friedrichs, Dr. Phil, is Associate Professor of Politics at the Department of International Development and Fellow of St Cross College, University of Oxford. His current research focuses on relations between Muslim minorities and non-Muslim majorities. He has published in journals such as International Organization, International Theory, Asian Survey, and Journal of Muslim Minority Affairs. His fifth book, on Hindu-Muslim relations, is due to appear in 2018. 
Intermestic security challenges arise when there is concern in a country that a dissatisfied minority relies on transnational bonds with a foreign kin-group for support. Ruling majorities and their governments, rightly or wrongly, may perceive such cross-border bonds as threatening because they solicit unwanted foreign support for dissatisfied minorities. This can lead to complications not only in domestic politics but also international relations (hence, the term 'intermestic').

To illustrate, consider the affinities of ethnic Russian minorities in Russia’s near abroad with Russia's majority. Until recently, scholars found that this was rather trouble-free. ${ }^{1}$ Ethnic Russians make up more than 20 percent in countries like Latvia or Kazakhstan, and they often face discrimination from ruling majorities and the state in their countries of residence. Yet, until recently, they hardly received support from Russia. This was due to deliberate Russian restraint which, today, does not seem to hold any longer. In early 2014, when Ukraine entered a political crisis, Russian-speaking rebels in the east and south of the country received support from Russia. It is debated to what extent that support arose from domestic groups within Russia and to what extent it was state sponsored. Regardless, it has posed a severe intermestic security challenge because it escalated an already tense situation into a full-blown war over secession.

\footnotetext{
${ }^{1}$ Charles King and Neil J. Melvin, 'Diaspora politics: ethnic linkages, foreign policy, and security in Eurasia,' International Security 24:3 (1999), pp. 108-138; Lars-Erik Cederman, Luc Girardin, and Kristian Skrede Gleditsch, 'Ethnonationalist triads: assessing the influence of kin groups on civil wars,' World Politics 61:3 (2009), pp. 403-437.
} 
Intermestic security challenges are observable all over the world and especially in Eurasia. In principle, they can be of an ethnic and of an ideological kind (or a combination of both). Transborder ethnic kinship plays an important role in many civil wars, from Pashtuns in Pakistan supporting the Taliban in Afghanistan to Kurds in Turkey supporting co-ethnics in Syria and Iraq. ${ }^{2}$ Ideologies shared across borders are of similar importance, with secular ideologies in decline since the end of the Cold War but religious ideologies, most notably transnational Islamism, on the rise. ${ }^{3}$ Ethnic and ideological bonds do not only contribute to civil wars but also to a variety of other political calamities such as state fragility, irredentism, or even interstate war. ${ }^{4}$

${ }^{2}$ Lars-Erik Cederman et al., 'Transborder ethnic kin and civil war,' International Organization 67:2 (2013), pp. 389-410; Arthur A. Stein, ‘Ethnicity, extraterritoriality, and international conflict,' Ethnic and Racial Studies 40:12 (2017), pp. 2020-2038.

${ }^{3}$ Eva Bernauer, Identities in Civil Conflict: How Ethnicity, Religion and Ideology Jointly Affect Rebellion (Wiesbaden: Springer, 2016); Barbara F. Walter, 'The new new civil wars,' Annual Review of Political Science 20 (2017), pp. 469-486.

${ }^{4}$ David R. Davis and Will H. Moore, 'Ethnicity matters: transnational ethnic alliances and foreign policy behavior,’ International Studies Quarterly 41:1 (1997), pp. 171-184; Stephen Saideman, The Ties That Divide: Ethnic Policies, Foreign Policy, and International Conflict (New York: Columbia University Press, 2001); Idean Salehyan, Rebels Without Borders: Transnational Insurgencies in World Politics (Ithaca, NY: Cornell University Press, 2009); David S. Siroky and Christopher W. Hale, 'Inside irredentism: a global empirical analysis,' American Journal of Political Sciences 61:1 (2017), pp. 117-128. 
Instead of studying such dismal scenarios, this article focuses on intermestic security challenges involving China's Muslim-majority neighboring countries that have not only not escalated into major conflict but also been successfully managed by Beijing and other governments.

\section{Intermestic security challenges}

This article makes three contributions. First, it offers a thorough conceptualization of intermestic security challenges to advance the emerging research agenda on the 'internal-external security nexus. ${ }^{5}$ It builds on existing literature referenced in the footnotes and offers a more elaborate theoretical model than has hitherto been available. Second, the article offers insight into how states can sometimes manage intermestic challenges. What can a government do to prevent transnational bonds from becoming a force multiplier for insurgents? How can it manage a situation where a dissatisfied minority might rely on transnational bonds for foreign support? Under what circumstances can governments forestall political destabilization and the escalation of violence? Third, the article examines specific empirical cases to sharpen the theoretical model and enable a better understanding of the causal processes involved. Research on further cases may then serve to test the model, modify it, or replace it with a better model should that be necessary. ${ }^{6}$

\footnotetext{
${ }^{5}$ Johan Eriksson and Mark Rhinhard, 'The internal-external security nexus: notes on an emerging research agenda,' Cooperation and Conflict 44:3 (2009), pp. 243-267.

${ }^{6}$ Incidentally, case selection is not tainted by confirmation bias as this research began as an investigation into China's relations with its Muslim-majority neighboring countries. The focus on intermestic security relations emerged later, in the actual process of studying the cases.
} 
The cases under study are all unlikely cases of successful management, where governments have been able to manage difficult intermestic security challenges against all odds. This is fortunate as we are more likely to derive important lessons from cases where, without prior knowledge, we would expect a high risk for the escalation of domestic and/or international conflict, but where governments have actually been successful in preventing or containing such escalation.

Why are my cases unlikely cases of success? Scholars have found that a 'transnational ethnic alliance' is more difficult to handle when a minority in Country A is dissatisfied but has foreign kin who share power, or are dominant in, a politically relevant nearby Country B. ${ }^{7}$ In such cases, the dissatisfied minority in Country A is part of a transnational constituency that is not only 'selfconscious and identifiable' but also 'politically salient' in Country B. ${ }^{8}$ Under such circumstances, the dissatisfied minority in A is likely to receive support from kin in B, exacerbating the challenge. Managing such a situation is difficult for the government of either country.

What is more, managing intermestic security challenges appears more difficult when ethnic kinship combines with ideological bonds. Ethnicity has always played a role in intermestic relations, but the role of ideology has changed. During the Cold War, communism was the most salient transnational ideological bond. After the decline of secular ideologies during the 1980s and

\footnotetext{
${ }^{7}$ Davis and Moore, 'Ethnicity matters;' Saideman, The Ties That Divide.

${ }^{8}$ Gary Winslett, ‘Differential threat perceptions: How transnational groups influence bilateral security relations,' Foreign Policy Analysis 12:4 (2016), pp. 653-673, at 654.
} 
1990s, various forms of political Islam have replaced communism in this role. ${ }^{9}$ Today, the worst intermestic challenges are those where transnational Islam and ethnic kinship combine.

All cases selected for study are about transnational bonds that are both ideological and ethnic, and invite foreign support from groups who share power, or are dominant, in relevant nearby countries. They all concern relations between China and its Muslim-majority neighboring countries, which is helpful to enhance comparability and control for other factors. During the Cold War, Malaysia and Indonesia were confronted with communist parties dominated by their ethnic Chinese minorities, raising concerns of foreign support from Maoist China. More recently, Beijing has been concerned that Uyghur insurgents in northwestern China may gain support from their Turkic co-ethnics and Muslim coreligionists in Central and South Asia. While these are unlikely cases of successful management in the ways outlined above, China and its Muslim neighboring countries have largely been able to manage either challenge against all odds.

This stands in contrast with the political experience elsewhere. India has struggled with Islamist groups supported by ideological kin in Pakistan, as well as the Pakistani 'deep state,' to the point of being targeted by foreign terrorists and fighting several wars over Kashmir. Similarly, Russia has been a major target of Islamist militants and has fought wars in the Caucasus. While China has been struggling with broadly comparable intermestic security challenges, Islamist and secessionist attacks have not reached a similar intensity, nor has China had to fight any such wars. Relations between China and its Muslim neighborhood are certainly not trouble-free, but they are better than relations between India, or Russia, and their respective Muslim neighborhoods.

\footnotetext{
${ }^{9}$ Walter, 'The new new civil wars.'
} 
The contrast shows just how unlikely successful management has been in the case of China and its Muslim-majority neighboring countries. This begs the question of how this has been possible and what, if anything, one may learn from it. The question is of obvious relevance. Europe, for instance, finds itself on the brink of comparable challenges. Western Europe has for a long time not fought any wars on its territory, but there was a 'Muslim factor' in the Balkan wars of the 1990s. More recently, Europe has been targeted by jihadists linked to Europe’s neighboring region south and east of the Mediterranean. ${ }^{10}$ In the Middle East itself, Sunni and Shia sectarianism have combined with ethnic kinship, notably but not exclusively among Arabs, posing significant intermestic security challenges to, and leading to the overturn of, several political regimes. ${ }^{11}$

The first section provides a conceptualization of intermestic security challenges, including the way they arise and can be managed. Subsequently, I present the evidence from my two cases.

- In the first case, China is at the receiving end of an intermestic challenge posed by the Uyghurs, a Turkic Muslim minority in China’s northwestern region of Xinjiang. China and its Muslim neighbors in Central and South Asia have managed the challenge by jointly containing the 'three evils’ of terrorism, separatism, and religious extremism.

\footnotetext{
${ }^{10}$ Thomas Hegghammer, ‘The Future of Jihadism in Europe: a pessimistic view,' Perspectives on Terrorism 10:6 (2016), pp. 156-170.

${ }^{11}$ Nader Hashemi and Danny Postel, eds., Sectarianization: Mapping the New Politics of the Middle East (London: Hurst, 2017); Vali Nasr, The Shia Revival: How Conflicts Within Islam Will Shape the Future, 2nd ed. (New York: Norton, 2016).
} 
- In the second case, Malaysia and Indonesia have been at the receiving end of a challenge posed by their ethnic Chinese minorities. In this case, the challenge receded in the 1990s when China managed to persuade Malaysia and Indonesia that the matter was moot as the ethnic Chinese were no longer receiving support from their ancestral homeland.

The conclusion shows that managing intermestic security challenges (rather than mismanaging them, or not managing them at all) can make a real difference for the stabilization of difficult political situations, and that further empirical research is likely to yield valuable further insights.

\section{Theoretical model}

Before proceeding to the empirical analysis, it is necessary to define intermestic security challenges and develop a rigorous framework for comparison. As a shorthand, an intermestic security challenge can be defined as a situation where there is concern in a country that a dissatisfied minority relies on transnational bonds with a foreign kin-group for support. ${ }^{12}$

\footnotetext{
${ }^{12}$ My use of the term 'intermestic' is different from, although loosely related to, the established use of the term in foreign policy and negotiation analysis. See for example Bayless Manning, 'The Congress, the executive and intermestic affairs: three proposals,' Foreign Affairs 55:2 (1977), pp. 306-324; Robert D. Putnam, 'Diplomacy and domestic politics: the logic of two-level games,’' International Organization 42:3 (1988), pp. 427-460.
} 
Figure 1 develops this into a theoretical model. An intermestic security challenge arises when three conditions are met: There are transnational bonds between a dissatisfied minority in Country A and a foreign kin-group in Country B; the minority in County A can rely on that bond for support; and, obviously, the Government of Country A sees this as a problem (Figure 1).

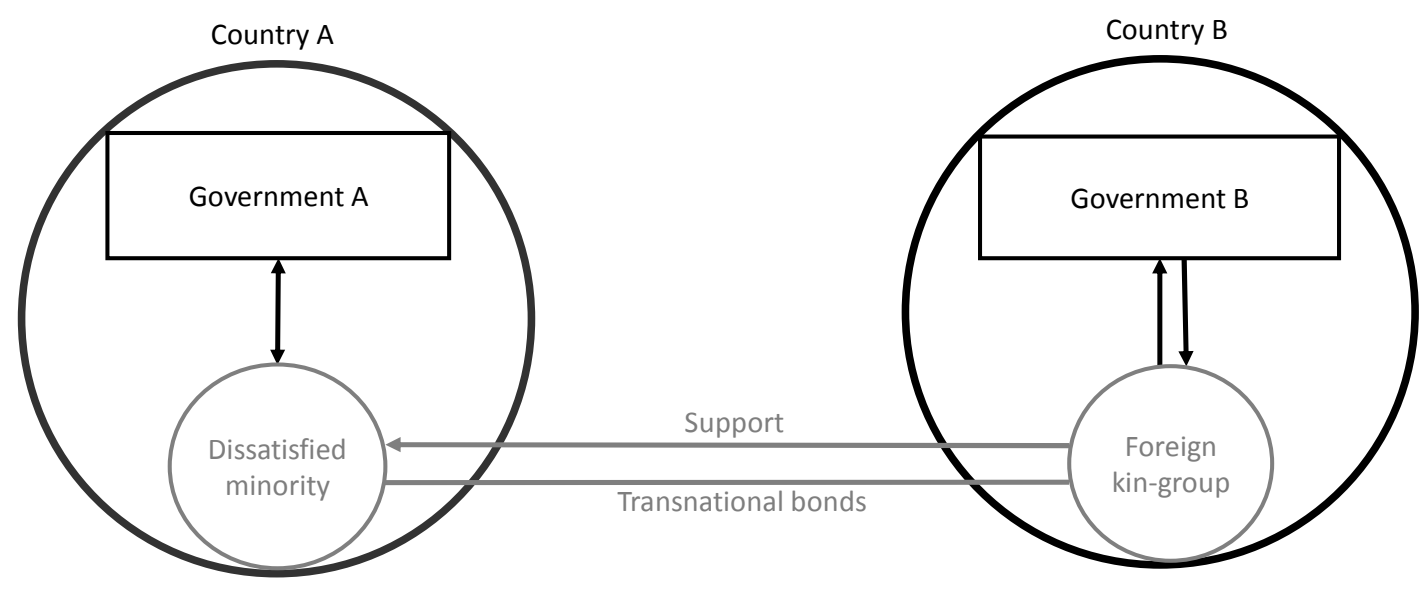

Figure 1: Intermestic security challenge

The transnational bond may be of an ethnic or ideological kind. If the bond is of an ideological kind, it may be constituted by a secular ideology like communism or by a religious ideology such as political Islam. The transnational bond may elicit different forms of foreign support: material and ideational, logistic and financial, and so on. Financial support may include transfers from a 
foreign diaspora and various other forms of conflict financing. ${ }^{13}$ It may also include regular remittances, proceeds from ethnic and trade networks and, potentially, transnational organized crime. ${ }^{14}$ That said, it is important not to underestimate the importance of ideational and logistic support. In the model above, all of these are subsumed under the broad category of foreign support. Such support is more likely when the foreign kin-group is aligned with the Government of Country B, and receives political patronage in return. The entire situation turns into an intermestic security challenge when two further conditions are met: the Government of Country A is in conflict with the dissatisfied minority, and perceives foreign support as unacceptable.

Perceptions can be warranted or not. Hence, an intermestic security challenge can be real or imagined (or both). Government A may imagine that a dissatisfied minority receives foreign support even when this is not the case; and even when there is foreign support, Government A may perceive this as a problem for domestic stability when in reality there is no such problem. In the

${ }^{13}$ Paul Collier and Anke Hoeffler, 'Greed and grievance in civil war,' Oxford Economic Papers 56:4 (2004), pp. 563-595; Achim Wennmann, 'The political economy of conflict financing: a comprehensive approach beyond natural resources,' Global Governance 13:3 (2007), pp. 427444. But note that diaspora financing in particular may have positive as well as negative effects. See Jeffrey T. Checkel, ed. Transnational Dynamics of Civil War (Cambridge: Cambridge University Press, 2013); Brandon Lum et al., 'Diasporas, remittances and state fragility: assessing the linkages,' Ethnopolitics 12:2 (2013), pp. 201-219. ${ }^{14}$ Trade links play a role in all cases under study. In Southeast Asia, diasporic links connecting the ethnic Chinese with their ancestral homeland are deeply resented. In the Uyghur case, Beijing has disrupted ethnic trade links to upend foreign support from Central and South Asia. 
long term, perceptions and reality are likely to align. If Government A is at loggerheads with a minority, it is almost certain to identify it as a problem when the minority can rely on foreign support. Conversely, if there is no foreign support then this will eventually sink in with Government $\mathrm{A}$, although that realization is far from automatic and may take considerable time. ${ }^{15}$

Given the intermestic nature of the challenge, a purely domestic strategy is unlikely to succeed. Apart from trying to disrupt the ability of the dissatisfied minority to access foreign support, Government A is also going to operate at the transnational and international level. At the transnational level, Government A will try to undermine the bond in order to counter any foreign support that might result from it. ${ }^{16}$ At the international level, Government A will want to enlist Government B in its strategy. This will in turn force Government B to develop its own strategy, either to accommodate or to antagonize Government A. As a result, Governments A and B will adjust their international relations, either towards intensified collaboration or towards greater confrontation. On either side, strategizing will thus take place at various levels (Figure 2).

\footnotetext{
${ }^{15}$ We will see this below in the case study on the ethnic Chinese minority in Indonesia.

${ }^{16} \mathrm{~B}$ may perceive A's transnational strategy as foreign interference and is likely to be lobbied in this direction by the (more or less influential) kin-group present on its territory.
} 


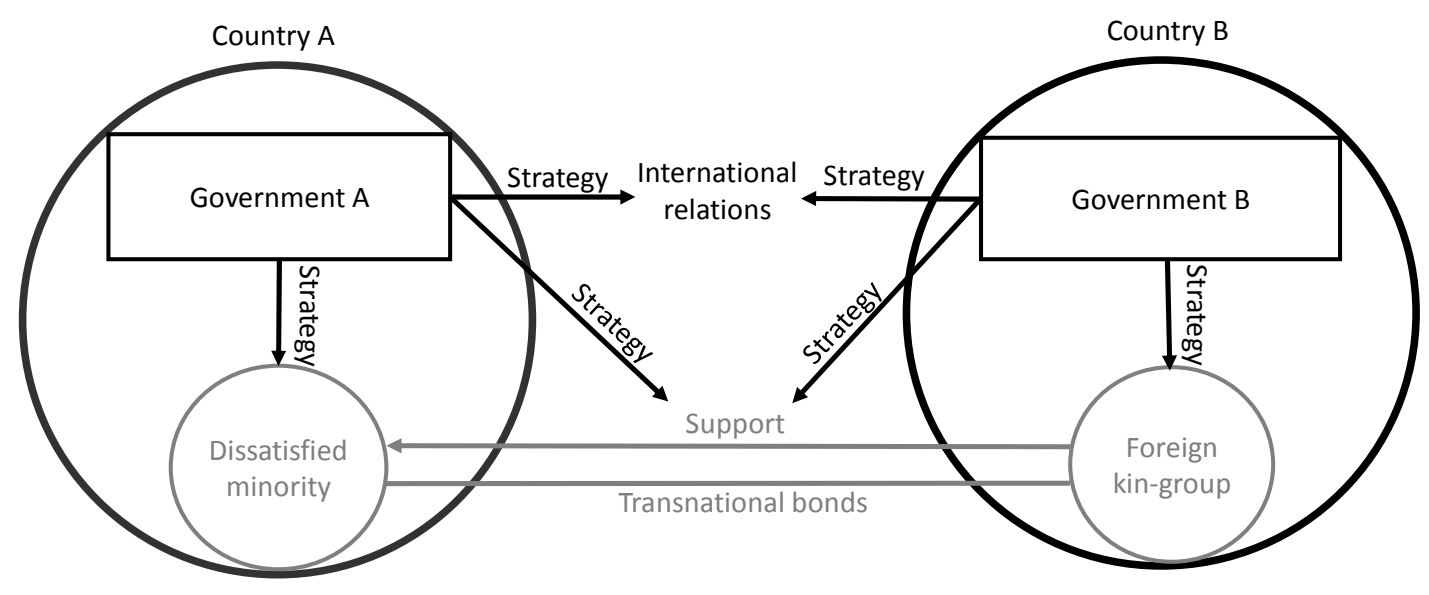

Figure 2: Management strategies

For Government A, the most important objective is to come to terms with the dissatisfied minority. For both governments, having positive relations is an important objective. Neither will want the intermestic challenge to escalate into a hot conflict, either domestically or at the international level. Tactical objectives at different levels can be in conflict with each other, but the ideal outcome and ultimate measure of successful management is when Government A is able to prevent the escalation of domestic conflict while having positive relations with Government B. ${ }^{17}$

\footnotetext{
${ }^{17}$ Intermestic security challenges are often linked with diaspora strategies. See Alan Gamlen, 'The emigration state and the modern geopolitical imagination,' Political Geography 27:8
} (2008), pp. 840-856; Francesco Ragazzi, ‘A comparative analysis of diaspora policies,’ Political 
Consider, for example, the Uyghurs in China’s restive northwestern border region of Xinjiang (domestic minority). As a Turkic Muslim ethnicity, the Uyghurs have links with ethnic kin and coreligionists in Central and South Asia (transnational bond). Beijing fears that Uyghurs may receive foreign support in pursuit of what China calls the 'three evils' of terrorism, separatism and religious extremism (intermestic challenge). Accordingly, Beijing adjusts its policy towards the Uyghurs and its relations with its Central and South Asian neighbors. The latter have been amenable and manage the challenge together with China (international relations).

Another case in point are the ethnic Chinese minorities in Indonesia and Malaysia (domestic minorities). The ethnic Chinese have diasporic links with their ancestral homeland (transnational bond). During the Cold War, there were concerns in Malaysia and Indonesia that communist China was supporting the ethnic Chinese, and this strained domestic relations with the ethnic Chinese in either country, which were already tense (intermestic challenge). At that time, the problem overshadowed diplomatic relations with China. After the Cold War, Beijing allayed Malaysian and Indonesian fears and relations became far more friendly (international relations).

Geography 41 (2014), pp. 74-89. This happens in two scenarios: when domestic minorities seek access to support from foreign kin-groups in pursuit of their goals, as with the Uyghurs; and when states exert 'extraterritorial reach to assert national influence over diaspora populations,' as with the ethnic Chinese during the Cold War. See Elaine Lynn-Ee Ho, 'New research directions and critical perspectives on diaspora strategies,' Geoforum 59 (2015), pp. 153-158, at 154. 


\section{Antecedent conditions}

Passing from theoretical model to empirical explanation, let us examine the causal factors that give rise to intermestic security challenges. My case studies are helpful for this purpose. It is hazardous to make wider inferences from a small number of cases. Nevertheless, the attempt can be revealing and generate plausible hypotheses that may 'travel' beyond the original cases.

Before the onset of the Chinese reform era, the Uyghurs did not pose an intermestic challenge to communist China. Malaysia and Indonesia, however, had a case that their ethnic Chinese minorities were posing a challenge. The situation was reversed after 1978. Since then, the Uyghurs have been an intermestic challenge for China. The ethnic Chinese, by contrast, have hardly posed a real challenge to Malaysia and Indonesia since the early 1980s. Thus, my cases comprise both periods when an intermestic challenge arose, and periods when it failed to arise.

Why have transnational bonds sometimes posed a challenge (ethnic Chinese before 1978; Uyghurs after 1978) when at other times they have not (Uyghurs before 1978; ethnic Chinese after 1978)? Table 1 provides an overview of the constellations of antecedent conditions leading to either outcome, as well as the sources of the intermestic challenges in the cases studied. 


\begin{tabular}{|l|c|c|}
\cline { 2 - 3 } \multicolumn{1}{c|}{} & \multicolumn{2}{c|}{ Transnational bonds } \\
\cline { 2 - 3 } \multicolumn{1}{c|}{} & Ethnic & Ideological \\
\hline $\begin{array}{l}\text { Ethnic Chinese, } \\
\text { pre-1978 }\end{array}$ & yes & yes \\
\hline $\begin{array}{l}\text { Ethnic Chinese, } \\
\text { post-1978 }\end{array}$ & yes & no \\
\hline $\begin{array}{l}\text { Uyghurs, } \\
\text { pre-1978 }\end{array}$ & yes & no \\
\hline $\begin{array}{l}\text { Uyghurs, } \\
\text { post-1978 }\end{array}$ & yes & yes \\
\hline
\end{tabular}

\begin{tabular}{|c|c|}
\hline \multicolumn{2}{|c|}{ Foreign support } \\
\hline Perceived & Actual \\
\hline yes & yes \\
\hline $\begin{array}{l}\text { Malaysia: no } \\
\text { Indonesia: until 1998 }\end{array}$ & no \\
\hline no & no \\
\hline yes & yes \\
\hline
\end{tabular}

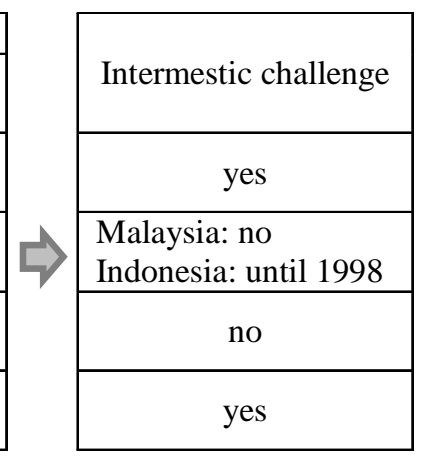

Table 1: Causal factors

In all cases under study there is an ethnic bond, but taken by itself it has limited causal power.

Ethnic affinity is certainly not sufficient to produce an intermestic security challenge. Whether before or after 1978, the Uyghurs and overseas Chinese have always had grievances that would appeal to foreign ethnic kin. Nevertheless, these grievances have led to an intermestic challenge in only two cases, and not in the other two. Hence, while ethnic affinity can lead to an intermestic security challenge, it will depend on other factors whether this actually happens.

Nor is ethnic affinity necessary for an intermestic challenge to arise. During the Cold War, for example, the Soviet Union and China supported communist insurgencies in the absence of ethnic affinity. Today, Islamist insurgents sometimes receive foreign support without ethnic affinity. There are plenty of cases where co-ethnics do not support their foreign kin. Even so, it seems clear that ethnic affinity makes the emergence of an intermestic challenge more likely. ${ }^{18}$

${ }^{18}$ Consider the Hui, another Muslim minority in China. China is home to more than 10 million Hui, most of whom speak Mandarin. Unlike the Uyghurs, the Hui are a socio-religious rather than an ethnic group. They would be Han were it not for the fact that they are Muslims. They are 
It seems that the presence or absence of an ideological bond has greater causal power. Until the 1970s, Maoism connected mainland China with important segments of the ethnic Chinese in Southeast Asia. This posed a serious intermestic security challenge to Indonesia and Malaysia. After the Cold War, when the demise of communism weakened that link, the challenge began to disappear. In the Uyghur case, transnational political Islam connects Muslims in Xinjiang with coreligionists in Central and South Asia. Before 1978, these links were largely absent. This was not only due to tight border controls and draconian oppression, but also because there was no significant ideological connector. It was only after the Iranian revolution and the Soviet invasion of Afghanistan, both of which occurred in 1979, that transnational political Islam became available as a transnational ideology to pose a significant challenge to powerful nation states.

Like ethnicity, ideology is neither necessary nor sufficient to produce an intermestic challenge. Ideological affinity cannot be a necessary condition because there are intermestic challenges even in its absence. For example, until the 1990s the Basques in France supported the Basques in Spain without any ideological reason, posing an intermestic challenge to Madrid. Nor can it be a sufficient condition because it is not the transnational bond as such that produces the challenge. An intermestic challenge only arises when the bond generates foreign support. This is not always the case. During the Cold War, there were plenty of communist movements all over the world, but even groups sharing the same ideology did not always support each other. After 1978, the Chinese Communist Party abandoned its support for ethnic Chinese communists. To cut a long

sometimes receptive to Middle Eastern models of Islam but, in the absence of cross-border ethnic affinities, this hardly poses a challenge. See Jörg Friedrichs, 'Sino-Muslim relations: the Han, the Hui, and the Uyghurs,' Journal of Muslim Minority Affairs 37:1 (2017), pp. 55-79. 
story short, it seems that ideological affinity makes the emergence of an intermestic challenge considerably more likely, especially when it comes on top of an ethnic bond.

It is important to note, however, that perceptions matter. Malaysia was quick to realize that its Chinese minority had ceased to receive support from China, and this is where the problem ended. Indonesia, by contrast, took until 1998 to come to the same realization (as the case study will show). Thus, in the Indonesian case, the intermestic challenge outlasted foreign support by as much as two decades. Sometimes it is enough if foreign support is only perceived.

Another interesting variable is whether or not a domestic minority is able to raise a territorial claim. It is important to note, however, that an intermestic security challenge may arise even in the absence of a territorial claim. Southeast Asia's ethnic Chinese have posed an intermestic challenge without being able to claim any particular part of Indonesia or Malaysia as their own. ${ }^{19}$ The Uyghur case, however, suggests that the ability to raise territorial claims is an aggravating factor. ${ }^{20}$ Consider the following thought experiment: Imagine that the Uyghurs, like the Hui, were dispersed all over China so that they could not raise a territorial claim over 'East Turkestan.' If that were so, it would mitigate the intermestic challenge posed by the Uyghurs.

${ }^{19}$ Ethnic Chinese approach demographic majority only in small and shattered areas like Penang, a state in northwest Malaysia that has almost 40\% Chinese (42\% Bumiputera), or in Singkawang, a Chinese-majority city of 200,000 inhabitants in the Indonesian province of West Kalimantan. ${ }^{20}$ Michael E. Clarke, 'Ethnic separatism in the People's Republic of China: History, Causes and Contemporary Challenges,' European Journal of East Asian Studies 12:1 (2013), pp. 109-133, at 111. 
In sum, a preliminary analysis suggests that intermestic security challenges result from a combination of ethnic and ideological affinities, when such affinities translate into foreign support that is seen as problematic. The ability to raise territorial claims is an aggravating factor.

\section{Causal trajectories}

After the analysis of antecedent conditions, let us move to the examination of causal trajectories. This helps uncover the actual processes underlying the model discussed in the last two sections. Moreover, it will enable us to extend the analysis to the eminently relevant question of strategy. What can states do about intermestic security challenges? How can they manage them?

In the Uyghur case, there was no intermestic challenge prior to 1978. China tightly controlled its territory, and political Islam had not yet (re)emerged as a transnational ideological bond. ${ }^{21}$ Since then, China's political decision to open itself for trade has unleashed an intermestic challenge, which in turn necessitated a management strategy. The following mechanism has been at work:

${ }^{21}$ Before the end of the Chinese Civil War in 1949, there had been two East Turkestan Republics looking to Soviet Central Asia. See Andrew D. W. Forbes, Warlords and Muslims in Chinese Central Asia: A Political History of Republican Sinkiang 1911-1949 (Cambridge: Cambridge University Press, 1986). In 1962, the Soviet Union briefly attempted to use the Uyghurs for ethnic destabilization. See Michael Freeberne, 'Minority unrest and Sino-Soviet rivalry in Sinkiang, China’s north-western frontier bastion, 1949-1965,' in Essays in Political Geography, ed.

Charles A. Fisher (London: Routledge, 2016 [reprint]), pp. 177-209. 

a. Political motivations led to liberalization moves.
b. Liberalization led to cross-border commerce and mobility of people.
c. Commerce and mobility invigorated transnational bonds.
d. Invigorated transnational bonds led to foreign support.
e. Foreign support led to real and perceived intermestic challenges.
f. These challenges led to-mostly successful—-political management. ${ }^{22}$

In the case of the ethnic Chinese, the countries challenged were Malaysia and Indonesia. Hence, one might expect that they should have pursued similar strategies. Interestingly, however, the decisive step in addressing the challenge was not so much Malaysian and Indonesian management but China's abstention from further supporting the ethnic Chinese. The causal mechanism at work was remarkably different from the one observed in the Uyghur case.

a. The perceived intermestic challenge was a legacy issue from the Cold War when the ethnic Chinese were seen as the "Fifth Column” of the Chinese Communist Party.

b. After the Cold War, communism declined as an ideological bond connecting mainland China and the ethnic Chinese, despite the continued existence of ethnic grievances.

c. Since then, China has largely abstained from supporting the ethnic Chinese.

d. Malaysia was quick to realize that the intermestic challenge had disappeared.

e. Indonesia came to the same realization considerably later, around 1998.

\footnotetext{
${ }^{22}$ As we will see, the Chinese strategy has unilateral elements but also rests on bilateral and multilateral cooperation with foreign governments to contain the challenge.
} 
f. In both cases, diplomatic relations with China eventually improved, and the situation of the ethnic Chinese became a merely domestic issue.

In either case, China has shown considerable stewardship in managing an intermestic challenge. In the Uyghur case, Beijing has leveraged its power and influence to prevent or stymie foreign support from Central and South Asia for Uyghur ethnic kin and/or coreligionists. In the case of the ethnic Chinese, deliberate Chinese self-restraint put the issue at rest after Maoism had lost its luster. Since then, Beijing has abandoned most of its erstwhile support for Southeast Asia's ethnic Chinese and left them at the mercy of the majority populations in their countries of residence, thus removing a key obstacle to the improvement of diplomatic and business relations.

There is interesting variation between the cases. In the Uyghur case, China is at the receiving end of an intermestic challenge that has deteriorated since 1978. In the case of the ethnic Chinese, China is the country from which the challenge used to emanate. The Uyghurs have a clear homeland in Xinjiang, enabling them to raise territorial claims. The ethnic Chinese have never been able to raise any territorial claim, and the challenge has evaporated since the end of the Cold War. Regardless of such differences, real or perceived foreign support for minorities has posed a challenge to domestic stability in either case, complicating international relations.

\section{China and its Muslim neighborhood}

China has more Muslim-majority neighboring countries than any other non-Muslim state. In Central and South Asia, China has land borders with five Muslim countries surrounding its Mus- 
lim-majority region of Xinjiang, the quintessential 'land of borderlands'²3: Kazakhstan, Kyrgyzstan, and Tajikistan, as well as Pakistan and Afghanistan. In Southeast Asia, China claims a further three Muslim-majority countries as its neighbors: Indonesia, Malaysia, and Brunei. ${ }^{24}$

A quick survey of China' Muslim neighborhood suggests that, in all cases, transnational bonds of domestic minorities with foreign kin-groups have complicated not only domestic politics but also interstate relations. In the case of China's Central Asian neighboring countries, as well as Pakistan and Afghanistan, there are Chinese concerns that Uyghur bonds with Turkic and/or Islamist sympathizers might undermine regional stability and exacerbate ethnoreligious unrest in Xinjiang and elsewhere in China. In Southeast Asia, there were and partly still are Malaysian and Indonesian concerns that ethnic Chinese citizens (or, initially, denizens) might be disloyal and draw on ancestral bonds with their motherland to betray their country of residence.

Kazakhstan, Kyrgyzstan, and Tajikistan are all former Soviet republics located in Central Asia. With the exception of the Tajiks, the titular nations of all Central Asian countries (also compris-

\footnotetext{
${ }^{23}$ Sean R. Roberts, ‘A “land of borderlands”: implications of Xinjiang’s trans-border interactions,' in Xinjiang: China's Muslim Borderland, ed. S. Frederick Starr (Armonk, NY: M.E. Sharpe, 2004), pp. 216-237.

${ }^{24}$ Given their divergent position on maritime borders, these countries do not see themselves as China’s neighbors. See M. Taylor Fravel, Strong Borders, Secure Nation: Cooperation and Conflict in China’s Territorial Disputes (Princeton: Princeton University Press, 2008); Bruce A. Elleman, Stephen Kotkin, and Clive Schofield, eds., Beijing's Power and China's Borders: Twenty Neighbors in Asia (Armonk, NY: M.E. Sharpe, 2013).
} 
ing Uzbekistan and Turkmenistan) are ethnic kin of the Uyghurs, belonging to the family of Turkic nations and speaking similar languages. Estimates vary, but Kazakhstan and Kyrgyzstan have a significant Uyghur diaspora. ${ }^{25}$ China fears that Central Asians might support their ethnic and religious kin in Xinjiang. Thus far, however, this has been thwarted by the harmony of interest between Beijing and the ruling elites of Central Asia’s newly independent states, each of which is more interested in nation building and regime stability than in any transnational agenda.

In South Asia, Beijing is even more concerned that Uyghurs might receive support from Islamists and/or Uyghur expats operating in Pakistan and Afghanistan. Ever since 1963, when China concluded border treaties with both countries, Pakistan has enjoyed a special relationship with China. At the onset, the linchpin was common enmity against India, with Beijing supporting Islamabad's territorial claims over Kashmir. The relationship has changed over the decades but remains positive, providing Beijing leverage to quell foreign support for Uyghurs from Pakistan. The Sino-Afghan border is only $92 \mathrm{~km}$ long, and China has made sure that it remains largely impermeable. Nevertheless, Afghanistan belongs to China’s strategic neighborhood as a breeding ground for regional instability and transnational terrorism. Beijing fears that Uyghur Islamists might infiltrate China from Afghanistan, most likely through Pakistan. ${ }^{26}$

${ }^{25}$ William Clark and Ablet Kamalov, 'Uighur migration across Central Asian frontiers,' Central Asian Survey 23:2 (2004), pp. 167-182; Marlène Laruelle and Sébastien Peyrouse, The Chinese Question in Central Asia: Domestic Order, Social Change and the Chinese Factor (London: Hurst, 2012).

${ }^{26}$ Fravel, Strong Borders, Secure Nation, pp. 116-119; see also Christopher Tang, 'The SinoPakistan border: stability in an unstable region,' in Beijing's Power and China's Borders: 
Malaysia and Indonesia are located at the opposite end of China, in Southeast Asia (leaving Brunei aside because of its small size and limited importance). Beijing claims them as neighbors in the South China Sea, although Southeast Asians have a different interpretation of the maritime border whereby China is not a neighbor. Especially Malaysia has a significant ethnic Chinese minority of 24.6 percent, down from 35.6 percent in $1970 .{ }^{27}$ Indonesia has a much smaller ethnic Chinese minority of 1.2 percent, down from $2-3$ percent at independence. ${ }^{28}$ In either country, some ethnic Chinese have accumulated considerable wealth, making them far more significant— and resented—-than percentages would suggest. ${ }^{29}$ During the Cold War, the ethnic Chinese in Malaysia and Indonesia were often seen as foreign proxies rather than loyal citizens. This has eased in recent years, although there remains anti-Chinese discrimination.

Twenty Neighbors in Asia, ed. Bruce A. Elleman, Stephen Kotkin, and Clive Schofield (Armonk, NY: M.E. Sharpe, 2013), pp. 219-233; Artemy M. Kalinovsky, 'Sino-Afghani border relations,' in Beijing's Power and China's Borders: Twenty Neighbors in Asia, ed. Bruce A. Elleman, Stephen Kotkin, and Clive Schofield (Armonk, NY: M.E. Sharpe, 2013), pp. 13-21.

${ }^{27}$ Department of Statistics Malaysia, Population and Housing Census of Malaysia: Population Distribution and Basic Demographic Characteristics (Putrajaya: Department of Statistics Malaysia, 2010); Chan Kok Eng and Tey Nai Peng, 'Demographic processes and changes,' in The Chinese in Malaysia, ed. Lee Kam Hing and Tan Chee-Beng (Oxford: Oxford University Press, 2000), pp. 71-93.

${ }^{28}$ Evi Nurvidya Arifin, M. Sairi Hasbullah, and Agus Pramono, ‘Chinese Indonesians: how many, who and where?,' Asian Ethnicity 18:3 (2017), pp. 310-329.

${ }^{29}$ Chee-Beng Tan, Routledge Handbook of the Chinese Diaspora (London: Routledge, 2013). 


\section{China and the Uyghurs}

The Uyghurs are one of China’s 55 ethnic minorities, made up of 10 Million Turkic Muslims. With 0.75 percent China's 1.3 billion people, the Uyghurs make up only a tiny fraction of the population. However, they are the largest ethnic group in the Xinjiang Uyghur Autonomous Region (47 percent), which covers more than one sixth of the Chinese territory and boasts significant mineral resources. Apart from the Uyghurs, China has nine other Muslim minorities, but none of them poses political challenges comparable to those posed by the Uyghurs. ${ }^{30}$

In recent years, Chinese authorities have been concerned that Uyghur Muslims in Xinjiang might be able to rely on transnational bonds with co-ethnics and/or co-religionists in Central and South Asia. President Xi Jinping said in April 2016: 'We must resolutely guard against overseas infiltrations via religious means and prevent ideological infringements by extremists. ${ }^{, 31}$

This has not always been so. During the Cold War, the Uyghur issue was frozen in time. ${ }^{32}$ Until the 1979 Iranian revolution, political Islam hardly played any role as a transnational ideology. Until the early 1980s, after the onset of the reform era, Chinese borders were closed. Beijing was

\footnotetext{
${ }^{30}$ Data from National Bureau of Statistics of China, Tabulation on the 2010 Population Census of the People's Republic of China (Beijing: China Statistics Press, 2013).

31 ‘Xi calls for improved religious work,' Xinhua, 23 April 2016.

${ }^{32}$ Before the end of the Chinese Civil War in 1949, there had been two East Turkestan Republics looking to Soviet Central Asia. See Forbes, Warlords and Muslims in Chinese Central Asia.
} 
able to foil attempts by foreign powers to exploit Uyghur discontentment for destabilization purposes. There was only one serious Soviet attempt to use the Uyghurs for ethnic destabilization, in 1962. ${ }^{33}$ American attempts to stir up the Uyghurs against Beijing were even more fanciful.

In the wake of Deng Xiaoping's reforms, the (re)opening of borders transformed China's relations with its Muslim neighboring countries in the west, conjuring up a mix of hopes and fears. The main hope was — and is — that trade will lead to prosperity, which in turn will reduce Uyghur discontent. The main fear is that, with cross-border commerce, ethnoreligious influences may creep in. That fear can hardly be dismissed, given the unstoppable rise of political Islam. Since the demise of the Soviet Union, Turkic solidarity has also contributed to the challenge.

Central Asian support for Uyghur insurgents is mostly associated with ethnic affinity (Turkic solidarity), whereas South Asian support is associated with ideological affinity (political Islam). In post-Soviet Central Asia, the space for religion is tightly controlled and restricted whereas nationalism is encouraged. Accordingly, Uyghur relations with the Turkic nations of Central Asia, as well as the Uyghur diaspora in the region, appear to strengthen ethnic rather than religious nationalism. This stands in contrast to support from Pakistan and Afghanistan, where society is seen as more religious and where strong Islamist movements are present. Besides, there are few significant Turkic ethnicities in South Asia to whose solidarity Uyghurs might appeal.

\footnotetext{
${ }^{33}$ Freeberne, 'Minority unrest and Sino-Soviet rivalry in Sinkiang.'
} 
As we will see, China and its Muslim neighbors in Central and South Asia have adopted a variety of tactics to manage the intermestic challenge, taking account of specific situations and circumstances in order to separate desirable interdependence from undesirable interference.

\section{Central Asia}

In the early reform years, Beijing's overtures towards Central Asia were not so much to promote business but rather for political gain. Opening borders promised three advantages. First, it would free western China from its marginal position in the Chinese economy, contributing to development and mitigating unrest. Political support for trade with Central Asia started in the 1980s and 1990s, was upgraded around 2000 under the 'Go West' or 'Great Western Development' campaign, and is now promoted under 'One Belt One Road' initiative, which includes the idea of a 'Silk Road Economic Belt. ${ }^{34}$ Second, it was hoped that Central Asian countries would view China's economic influence as benign rather than violating their sovereignty. Third, interdependence with Central Asia would be highly asymmetrical, allowing China to grow into an indispensable partner. This would increase Chinese leverage over Central Asian leaders, for instance to quell Uyghur diaspora mobilization. State structures in Xinjiang embraced the policy. ${ }^{35}$

\footnotetext{
${ }^{34}$ Michael E. Clarke, Xinjiang and China's Rise in Central Asia: A History (London: Routledge, 2011), pp. 129-156; Colin Mackerras, ‘Xinjiang in China’s foreign relations: part of a new silk road or Central Asian zone of conflict?,' East Asia 32:1 (2015), pp. 25-42.

${ }^{35}$ Niklas Swanström, ‘Central Asia and China’s security policy,' in Routledge Handbook of Chinese Security, ed. Lowell Dittmer and Maochun Yu (London: Routledge, 2015), pp. 229-240.
} 
While trade between China and Central Asia retains a political dimension, it has since acquired an economic dynamic of its own. This is so because private and semi-private enterprises in China are increasingly autonomous from the state. In their trade and investment decisions, even stateowned companies tend to follow business motivations. What is more, existing trade links have led to relationships of genuine interdependence that would be costly to disrupt.

In Kyrgyzstan, for example, business relations have gained enormous momentum. After the settlement of border disputes in 1999, Kyrgyzstan's trade with China grew rapidly. As the only Central Asian WTO member, Kyrgyzstan became an important destination and transit zone for Chinese goods. By the late 2000s, goods from China made up 94 percent of Kyrgyzstan's crossborder commerce. In 2011, at least 75 percent of the merchandize at Kyrgyzstan’s two largest bazaars originated from China. An army of shuttle traders are in the business of re-exporting goods imported from China to other Central Asian States and Russia. ${ }^{36}$ China has also grown into an important partner for Kazakhstan in terms of infrastructure and commodity exports.

Unfortunately for Beijing, trade with Central Asia had undesirable side effects. At the downfall of the Soviet Union, when the Central Asian republics became independent, some Uyghurs were hoping that they, too, might obtain their own Muslim-majority nation state. What is more, they were hoping that the Uyghur diaspora in Central Asia might help them reach this objective.

\footnotetext{
${ }^{36}$ Erika Marat, ‘Kyrgyzstan: China’s regional playground?,' in Beijing’s Power and China’s Borders: Twenty Neighbors in Asia, ed. Bruce A. Elleman, Stephen Kotkin, and Clive Schofield (Armonk, NY: M.E. Sharpe, 2013), pp. 127-141, at 136.
} 
Partly spurred by that diaspora, there was popular support in Central Asia for the liberation of East Turkestan, or 'Uyghurstan,' as yet another Turkic-Muslim nation state. ${ }^{37}$

With increasing cross-border mobility, it became harder for Beijing to control this ferment. There was reason for concern that regime change in Central Asia might bring to power governments that would place greater emphasis on ethnic kinship and Islamic religion shared with the Uyghurs. In the event of an Islamist takeover in a Central Asian country, the new regime might allow Uyghur expatriates more leeway. As China became reliant on strategic infrastructure such as pipelines from Central Asia, it also became vulnerable to attacks on such infrastructure. Therefore, Beijing has a vested interest in the stabilization of Central Asian regimes. ${ }^{38}$

While Beijing sometimes exaggerated the threat from Central Asia, it did have reason to be on its guard. During the late 1980s and early 1990s, Uyghurs gained considerable wealth as itinerant merchants, trading Chinese consumer goods for commodities from Central Asia and acting as middlemen between Han Chinese and Central Asian traders. Some of that wealth was used for building mosques and other community institutions. Part of it was also used to promote Uyghur ethno-nationalism, as in the case of the notorious Uyghur activist Rebiya Khadeer. ${ }^{39}$

\footnotetext{
${ }^{37}$ Clark and Kamalov, 'Uighur migration across Central Asian frontiers;' Eric Hyer, 'China’s policy towards Uighur nationalism,' Journal of Muslim Minority Affairs 26:1 (2006), pp. 75-86. ${ }^{38}$ Swanström, 'Central Asia and China’s security policy.'

${ }^{39}$ Roberts, ‘A “land of borderlands,”’ pp. 220-225; Hasan H. Karrar, 'Merchants, markets, and the state: informality, transnationality, and spatial imaginaries in the revival of Central Eurasian trade,' Critical Asian Studies 45:3 (2013), pp. 459-480, at 466-467.
} 
Anti-Chinese resentment in Central Asia has been another challenge. Especially in Kyrgyzstan and Kazakhstan, some people see Chinese influence in a negative light. Chinese merchants often outperform locals on bazaars and in factories, which can lead to considerable animosities. In Kyrgyzstan, there is resentment against Chinese merchants and workers living in segregated communities despite the fact that many of them are Muslim, presumably of Hui extraction. In Kazakhstan, there is hostility towards illegal Chinese immigrants. In 2004 and 2009, when Chinese authorities approached Kazakhstan to lease land for thousands of colonists to grow staples like soybeans and wheat, there were severe anti-Chinese protests. Recent charm offensives appear to have had relatively limited effect in Kazakhstan and, especially, Kyrgyzstan. ${ }^{40}$

Given the intermestic nature of these challenges, Beijing has responded both at the domestic and at the international level. At the domestic level, Chinese authorities have insulated the Uyghurs from Central Asia. From the late 1990s, when shuttle trading gave way to wholesale purchasing, the Uyghur middlemen were largely cut out. Since then, Central Asian traders mostly deal directly with Han or, eventually, Hui business partners. ${ }^{41}$ Since the 2009 Urumqi riots, Uyghur truck drivers have been unable to obtain licenses for driving oil tankers. Although not officially

${ }^{40}$ Laruelle and Peyrouse, The Chinese Question in Central Asia, pp. 103-114; Sébastian Peyrouse, 'Discussing China: sinophilia and sinophobia in Central Asia,' Journal of Eurasian Studies 7:1 (2016), pp. 14-23, at 21-22; Julie Yu-Wen Chen and Soledad Jiménez Tovar, 'China in Central Asia: local perceptions from future elites,' China Quarterly of International Strategic Studies 3:3 (2017), pp. 1-17.

${ }^{41}$ Roberts, ‘A “land of borderlands”’, pp. 220-225; Laruelle and Peyrouse, The Chinese Question in Central Asia, pp. 117-123. 
stated, it seems that the authorities see them as potential suicide attackers. ${ }^{42}$ The authorities are also reluctant to issue travel documents to Uyghurs-especially to students seeking permission to study abroad, to prevent them from exposure to nationalist and/or Islamist ideas. ${ }^{43}$

At the international level, Beijing wants to ensure that its neighbors have zero tolerance for proUyghur mobilization. In order to do so, China has embarked on intense cooperation with the Central Asian successor states of the Soviet Union. Over the 1990s, China settled all border disputes on terms favorable to its Central Asian neighbors, starting with Kazakhstan and ending with Tajikistan. ${ }^{44}$ Since Central Asian governments share China’s view of religious nationalism as a threat to regime stability, they are mostly happy to curb Uyghur mobilization. China often obtains the imprisonment or extradition of Uyghur activists, or at least a curtailment of their room of maneuver. Kazakhstan in particular is an important ally against Uyghur separatism. ${ }^{45}$

\footnotetext{
${ }^{42}$ Andrew Jacobs, 'Uyghurs in China say bias is growing,' New York Times, 8 October 2013.

${ }^{43}$ Joanne Smith Finley, The Art of Symbolic Resistance: Uyghur Identities and Uyghur-Han Relations in Contemporary Xinjiang (Leiden: Brill, 2013), p. 252.

${ }^{44}$ Fravel, Strong Borders, Secure Nation, pp. 156-166.

${ }^{45}$ Stephen Blank, ‘Kazakhstan’s border relations with China,' in Beijing’s Power and China's
} Borders: Twenty Neighbors in Asia, ed. Bruce A. Elleman, Stephen Kotkin, and Clive Schofield (Armonk, NY: M.E. Sharpe, 2013), pp. 97-109. This is not to deny that there has been popular backlash, especially with regard to the border agreements. In Kyrgyzstan, protests against the border treaty contributed to the downfall of president Akayev in 2005. In Tajikistan, the opposition contested the 2011 border agreement despite the fact that the mountainous areas in question 
In addition to these bilateral efforts, China has used the Shanghai Cooperation Organization (SCO; 'Shanghai Five' until 2001) to manage the intermestic challenge posed by the Uyghurs. Apart from trying to improve the stability of Central Asian regimes, Beijing wants the SCO to fight the 'three evil forces' of terrorism, separatism, and extremism. ${ }^{46}$ China is the only member of the SCO that has a significant separatist movement, so the reference to 'separatism' is clearly on Chinese instigation. ${ }^{47}$ Beijing's aim is to boost the capacity and willingness of its neighbors to restrain any support for the Uyghurs emanating from their territory. Under the auspices of the SCO, exercises take place almost every year to harden security forces for the fight against real or perceived terrorists, separatists, and extremists. At least 21 drills took place from 2002 to 2015, with thousands of military and police simulating a robust response to various threats. ${ }^{48}$

were hardly populated. While such domestic backlash has been a nuisance to Central Asian regimes, the agreed stabilization of international borders is a significant accomplishment. See Laruelle and Peyrouse, The Chinese Question in Central Asia, pp. 13-25; see also the relevant chapters in Elleman, Kotkin, and Schofield, Beijing's Power and China's Borders.

${ }^{46}$ Stephen Aris, ‘The Shanghai Cooperation Organization: “tackling the three evils,” EuropeAsia Studies 61:3 (2009), pp. 457-482.

${ }^{47}$ Michael E. Clarke, 'Xinjiang and the trans-nationalization of Uyghur terrorism: cracks in the “New Silk Road”?,' Asan Forum, 10 February 2017.

${ }^{48}$ Marcel de Haas, 'War games of the Shanghai Cooperation Organization and the Collective Security Treaty Organization: drills on the move!,' Journal of Slavic Military Studies 29:3 (2016), pp. 378-406. 


\section{Pakistan and Afghanistan}

While Pakistan does not have any significant indigenous Turkic minorities (Afghanistan does have some, but the Pashtuns are dominant), political Islam is an important social and political force. Unsurprisingly, therefore, China’s intermestic challenge from South Asia is associated with religious rather than ethnic affinities. This is different from Central Asia, as we have seen. Nevertheless, the cycle has been similar in both cases: liberalization policies invigorated not only cross-border commerce and mobility of people but also transnational bonds with, and foreign support for, the Uyghurs; this has posed real and perceived intermestic challenges, which in turn have prompted both sides to undertake measures geared towards managing those challenges.

In the Pakistani case, this has unfolded in the context of Islamabad's famous special relationship with Beijing. ${ }^{49}$ In 1959, at a time when China was internationally isolated, China and Pakistan started building the Karakoram Highway (known in China as the Friendship Highway), connecting Islamabad with Kashgar in Xinjiang. In 1963, the two countries concluded a border agreement settling all territorial disputes. ${ }^{50}$ In the first few years after the agreement, China backed Pakistan’s territorial claim for the Indian part of Kashmir. Over the 1970s, Chinese support for Pakistan, including the Pakistani nuclear program, took a more covert form compatible with the simultaneous cultivation of relations with India. Even though China has since been keen to avoid

\footnotetext{
${ }^{49}$ Andrew Small, The China-Pakistan Axis: Asia’s New Geopolitics (New York: Oxford University Press, 2015).

${ }^{50}$ Fravel, Strong Borders, Secure Nation, pp. 116-118.
} 
symbolic gestures towards Pakistan that might unnecessarily antagonize New Delhi, Beijing and Islamabad keep emphasizing that the 'all weather' special relationship continues. ${ }^{51}$

Initially, the motivation was plainly political. The Karakoram Highway, through which Sino-Pakistani trade must pass, was constructed between 1959 and 1979 for military purposes, including the provision of Pakistan with ballistic missiles and nuclear weapons. From the early 1980s, with the onset of the Chinese reform period, commercial motivations came to the fore. The Highway opened to the public in 1986. More recently, China has tried to intensify its links with Pakistan by developing an economic corridor, including a railway and a pipeline, from Gwadar, a harbor in the Pakistani region of Baluchistan, via the Karakoram all the way to Xinjiang. If successful, this may bring the Persian Gulf and notably Iran into China’s strategic neighborhood. ${ }^{52}$

As in the Central Asian case, Sino-Pakistani interdependence is asymmetrical. China is more important for Pakistan than Pakistan is for China, and many Chinese exports are politically motivated—notably arms deals and critical infrastructure. The similarities do not end here. As in the Central Asian case, the Sino-Pakistani relationship has developed an economic dynamic of its own, as trade along the Karakoram Highway became a significant conduit for commerce.

In the early reform era, the hallmark of Sino-Pakistani commerce was the exchange of unsophisticated Pakistani staples for somewhat more sophisticated Chinese products. On the Chinese side, the trade primarily involved small Uyghur entrepreneurs buying and selling goods on Pakistani

\footnotetext{
${ }^{51}$ Mathieu Duchâtel, ‘The terrorist risk and China’s policy toward Pakistan: strategic reassurance and the "United Front,"' Journal of Contemporary China 20:71 (2011), pp. 543-561.

${ }^{52}$ Tang, 'The Sino-Pakistan border.'
} 
bazaars and/or trucking them to China. ${ }^{53}$ By the early 1990s, however, Chinese authorities became wary that Sino-Pakistani commerce was conjuring up unwanted religious and cultural influence of Pakistani Muslims on their Uyghur coreligionists. Women in southern Xinjiang began wearing veils in areas where this had not been common for generations. Aspiring clerics went to Pakistan for religious training. Pakistan was also important for Uyghurs as a transit country on the way to Mecca and other destinations in the Middle East. Some Uyghurs studied at radical madrassas in Pakistan. A few even found their way to Taliban-controlled Afghanistan (22 noncombatant Uyghurs were arrested in Afghanistan and subsequently held at Guantanamo). Some Uyghurs came back radicalized, while others chose to permanently settle in Pakistan. ${ }^{54}$

Beijing did have reason to be on its guard. During the 1980s, China had supported the Mujahedin in Afghanistan. ${ }^{55}$ From 1989, when Uyghur unrest started to intensify, Beijing was concerned that religious extremism might spill back into China. Such concerns became more intense in April 1990 when, according to Chinese sources, an Islamist uprising in the Uyghur township of Baren was instigated by Islamists who had infiltrated Xinjiang from Pakistan and Afghanistan. ${ }^{56}$

53 Ziad Haider, 'Sino-Pakistan relations and Xinjiang’s Uighurs: politics, trade, and Islam along the Karakoram Highway,' Asian Survey 45:4 (2005), pp. 522-545.

54 Ibid., pp. 525-531; Roberts, ‘A “land of borderlands,”’ pp. 229-231.

${ }^{55}$ Small, The China-Pakistan Axis, pp. 123-126.

${ }^{56}$ Yitzhak Shichor, 'The great wall of steel: military and strategy in Xinjiang,' in Xinjiang:

China’s Muslim Borderland, ed. S. Frederick Starr (Armonk, NY: M.E. Sharpe, 2004), pp. 120160, at 157-158; Michael Dillon, Xinjiang: China's Muslim Far Northwest (London: Routledge, 2004), pp. 139-141; Clarke, Xinjiang and China’s Rise in Central Asia, pp. 91-95. 
Since then, this has remained a concern. In 1999, Beijing complained that Uyghur militants had received training on Pakistani soil. ${ }^{57}$ The Chinese stance hardened further after 9/11, when the international community endowed ‘counterterrorism’ with greater legitimacy. In 2009, China put significant pressure on Pakistan to crack down on Islamist militants suspected of planning attacks in Xinjiang. ${ }^{58}$ In 2013, there was another bout of Chinese outrage at the presence of Uyghur militants in Pakistan's region of North Waziristan. ${ }^{59}$ In 2017, a newspaper from Hong Kong reported that Beijing had deported scores of Pakistani students after a 'blast' in Urumqi, Xinjiang, and urged universities across the country for caution when admitting Pakistanis. ${ }^{60}$

What were the actual policies adopted to manage the challenge? As a first line of defense, Chinese authorities resorted to unilateral measures. In 1992, Beijing closed the Karakoram Highway for several months. Subsequently, trade across the Highway was repeatedly disrupted by Chinese efforts to curtail transnational ethnoreligious links and curb drug smuggling. Fearful that the Karakoram might become a conveyor of radicalism, Beijing announced the intention of installing a border fence in 1997. Subsequently, Beijing constructed barbed-wire fences at the Khunjerab. ${ }^{61}$

\footnotetext{
${ }^{57}$ Shichor, ‘The great wall of steel,' pp. 144-145.

${ }^{58}$ Omar Waraich, 'China calls on Zardari to take action against rebels,' Independent, 8 April 2009.

59 ‘A friend in deed,' Friday Times, 8 November 2013.

${ }^{60}$ Asian News International, 'Is Beijing concealing Pakistan-linked terrorism in Xinjiang?,' Asian News International, 3 January 2017.

${ }^{61}$ Haider, 'Sino-Pakistan relations and Xinjiang’s Uighurs,' pp. 525-532.
} 
Beijing's second and more successful response was to drive a wedge between Uyghurs and Pakistanis by reconstituting the Karakoram trade. Field research suggests that, in the late 1990s, Pakistani traders were forced to abandon their Uyghur coreligionists in favor of Han patrons and business partners. Some Pakistani traders even married local women, preferably Han, to ensure better access to visa. Around the same time, Uyghur truck drivers gave way to Han drivers. Whether intended or not, the decline of Uyghur involvement in Sino-Pakistani trade damaged relations between Uyghurs and Pakistanis. An additional source of resentment was that some Pakistani traders used their stays in Xinjiang to drink alcohol and/or sleep with Uyghur women. Ethnographic research shows that Pakistani merchants painted Uyghurs as bad Muslims and drunkards, and their women as given to promiscuity and prostitution, thus rationalizing their opportunistic embrace of Han patronage and un-Islamic sexual liaisons. Uyghurs, in turn, painted Pakistanis as ruthless economic profiteers and unscrupulous womanizers and fornicators. ${ }^{62}$

This does not only sound ugly, it actually was. However, it has been successful in terms of Beijing’s objectives. By forcing Pakistani tradesmen to transfer lucrative business relations from Uyghur to Han partners, Beijing has driven a wedge between Uyghurs and Pakistanis, reducing the exposure of Uyghurs to unwanted religious and cultural influence. Mutual recriminations have left limited room, if any, for transnational Islamic solidarity. Undaunted by the persecution of Uyghurs, Pakistanis hold a more favorable view of China than any other nation. ${ }^{63}$

\footnotetext{
62 Ibid., pp. 525-531, 538-544.

${ }^{63}$ See http://www.pewglobal.org/database/indicator/24/survey/17/, accessed 22 October 2017. This is in contrast with China's mixed reputation among the public in Central Asia (see above).
} 
This brings us to Beijing's third response, bilateral cooperation. Worries about extremist or terrorist elements infiltrating Xinjiang loom large in Sino-Pakistani relations. To mitigate that risk and gain leverage, Chinese authorities cultivate intense inter-agency linkages with Pakistani counterparts, while also directing public diplomacy efforts at Pakistani Islamist parties such as Jamaat-e-Islami (JI) and Jamiat Ulema-e Islam (JUI). For the same purpose, China and Pakistan conduct a bilateral counterterrorism drills every two years. The scenarios played out in these exercises are highly revealing. In 2004, for example, the drill simulated an attempt by terrorists on horseback and light motorized vehicles to infiltrate Xinjiang via Pakistan from a 'third country,' presumably Afghanistan (on Sino-Afghan relations, see Box 1). ${ }^{64}$

The Sino-Afghan border at the end of the Wakhan corridor is very short (92 km), highly impervious, and commercially insignificant. Despite a 1963 agreement settling all territorial issues, Beijing remains unwilling to open the border due to concerns about transnational linkages between Afghan and Uyghur Islamists. Beijing's refusal to collaborate with the US-led occupation in Afghanistan did not prevent China from cultivating economic links. As in the Iraqi oil sector after the 2003 War, China has invested billions of dollars in a copper deposit near Kabul. Subsequently, however, the mine languished due to security and transportation problems. ${ }^{65}$

Prior to the withdrawal of US forces from Afghanistan, Beijing operated via Pakistan. At the time, Beijing's goal was to prevent the spill-back of jihadism from Afghanistan via Pakistan into China, rather than fighting jihadists in Afghanistan. This has now started to change. After a series of kidnappings and attacks on Chinese facilities, Beijing has become more directly involved in

\footnotetext{
${ }^{64}$ Duchâtel, ‘The terrorist risk and China’s policy toward Pakistan,’ pp. 551-555.

${ }^{65}$ Kalinovsky, 'Sino-Afghani border relations’; Small, The China-Pakistan Axis, pp. 117-144.
} 


Afghanistan to hedge against 'worst-case scenarios.' In September 2012, China's domestic 'se-
curity czar,' Zhou Yongkang, visited Kabul. In February 2015, presumably on Chinese instiga-
tion, Afghan government forces arrested 15 Uyghur militants in Kunar Province. In 2016, China
played a much-publicized role in the resumption of peace talks with the Taliban. In 2017, China
has conducted military or paramilitary operations across the border in Afghanistan, in line with
its counterterrorism law of 2015 which allows for the possibility of operating abroad. ${ }^{66}$

Box 1: Sino-Afghan relations

Overall, Beijing has been successful. Officially, Islamabad has never supported the Uyghurs. Chinese experts contend that unofficial Pakistani links with Uyghur militants have weakened since the mid-1990s. On several counts, Beijing has successfully pressurized Islamabad to arrest and extradite Uyghur militants. After the suppression of the 2009 Urumqi riots, there were motions to include the issue on the agenda of the Organization of the Islamic Conference (OIC). However, Beijing was able to rely on Islamabad to prevent this from happening. ${ }^{67}$

\footnotetext{
${ }^{66}$ Small, The China-Pakistan Axis, pp. 130-164; Michael E. Clarke, ““One Belt, One Road” and China’s emerging Afghanistan dilemma,' Australian Journal of International Affairs 70:5 (2016), pp. 563-579; Clarke, 'Xinjiang and the trans-nationalization of Uyghur terrorism;' 'Beijing’s foray into the graveyard of empires,' Financial Times, 3 March 2017.

${ }^{67}$ Duchâtel, ‘The terrorist risk and China’s policy toward Pakistan,’ pp. 549, 551; Haider, ‘SinoPakistan relations and Xinjiang’s Uighurs,' pp. 535-537.
} 
Nevertheless, Uyghur militants may receive covert support from the Pakistani 'deep state’ (most notably the Inter-Services Intelligence, ISI). Islamabad is also struggling to protect Chinese nationals working in Pakistan. Due to the dismal security situation, Chinese engineers and expat workers are sometimes kidnapped or killed on duty. ${ }^{68}$ In dramatic event in 2007, Chinese 'massage workers' were kidnapped by Islamists at the Red Mosque, in the heart of Islamabad. When China was seen as having pressurized Islamabad to assault the mosque, with at least 103 people including 12 Uyghurs killed, gunmen shouting religious slogans murdered three Chinese engineers. Subsequently, a Chinese-Pakistani task force was established to address the threat to at least 10,000 Chinese citizens working in Pakistan. Even though Islamabad offered the provision of direct military protection, Beijing’s trust in Islamabad’s capacity and goodwill remains limited. ${ }^{69}$

\section{Malaysia, Indonesia, and the ethnic Chinese}

Chinese support for ethnic Chinese living in Malaysia and Indonesia has sometimes been seen as an intermestic challenge. Some ethnic Chinese are enormously rich tycoons. Others are engaged in lowly occupations such as farm labor and mining. While the Chinese diaspora is highly di-

\footnotetext{
68 Tang, 'The Sino-Pakistan border,' p. 228; Duchâtel, 'The terrorist risk and China’s policy toward Pakistan,’ pp. 543-548.

${ }^{69}$ Small, The China-Pakistan Axis, pp. ix-xvi, 111-112.
} 
verse, indigenous Indonesians and Malaysians saw reason to resent the economic wealth of ethnic Chinese elites. At the same time, they distrusted the civic loyalty of ethnic Chinese workers who, during the Cold War, were notorious recruiting grounds for communist parties. ${ }^{70}$

In the aftermath of decolonization, the ethnic Chinese in Indonesia and Malaysia were widely regarded as Beijing’s 'Fifth Colum.' Especially during the 1960s and early 1970s, Beijing officially tried to export the revolution. In Southeast Asia, this meant patronizing the overseas Chinese and their communist parties. ${ }^{71}$ This in turn led to significant distrust of the ethnic Chinese, and of China as their foreign sponsor. Given the clandestine nature of Chinese interference, it was easy to overstate its significance and use it to legitimize anti-Chinese demagogy. In the heady days of the Cold War, one could always scapegoat China and the Chinese. ${ }^{72}$

At the time, newly independent Indonesia and Malaysia were striving to build nations from complex patchworks of ethnicities. In either country, a majority that saw itself as indigenous (bumiputera in Malaysia, pribumi in Indonesia) resented the wealth of Chinese business elites. At the

\footnotetext{
${ }^{70}$ Chinese merchants have been present in Southeast Asia since time immemorial. Mass immigration of 'coolies' from South China dates back to the second half of the nineteenth century. See Adam McKeown, ‘Conceptualizing Chinese diasporas, 1842 to 1949,’ Journal of Asian Studies 58:2 (1999), pp. 306-337.

${ }^{71}$ John W. Garver, China's Quest: The History of the Foreign Relations of the People's Republic of China (New York: Oxford University Press, 2016), pp. 196-231; Peter Van Nees, Revolution and Chinese Foreign Policy (Berkeley: University of California Press, 1970). ${ }^{72}$ Stephen Fitzgerald, China and the Overseas Chinese: A Study of Peking's Changing Policy, 1949-1970 (Cambridge: Cambridge University Press, 1972).
} 
same time, ethnic Chinese communists were suspected of being loyal to their ancestral homeland rather than their country of residence. In a situation where relations between indigenous Muslim majorities and ethnic Chinese minorities were already tense, the suspicion of foreign support could serve as an excuse for anti-Chinese mobilization. Populist leaders depicted the ethnic Chinese elites as an exploitative, and Chinese commoners as an unpatriotic 'other' to justify discrimination and persecution. Given their strong resonance with popular resentment, such anti-Chinese scapegoating played an important role in bolstering regime legitimacy.

Until the 1970s, it was easy to dismiss Beijing’s denials. After all, Malaysia and Indonesia had communist parties looking to Beijing for propaganda. Quite evidently, most of their members were ethnic Chinese. Even in the absence of hard evidence, one could claim that local communist parties were receiving political and financial support from the Chinese Communist Party. What is more, Beijing occasionally offered Southeast Asia's ethnic Chinese the possibility of opting for Chinese citizenship, nurturing further suspicion regarding their civic loyalty. ${ }^{73}$

In 1980, however, China promulgated a new nationality law that officially removed the option of Chinese citizenship for all those who had permanently settled abroad and accepted citizenship there. ${ }^{74}$ Around the same time, Beijing started emphasizing the benefits of international trade

\footnotetext{
${ }^{73}$ Indira Ramanathan, China and the Ethnic Chinese in Malaysia and Indonesia, 1949-1992 (London: Sangam, 1994).

${ }^{74}$ Leo Suryadinata, 'China's nationality laws and the Chinese overseas,' in Indian and Chinese Immigrant Communities: Comparative Perspectives, ed. Jayati Bhattacharya and Coonor
} Kripalani (London: Anthem Press, 2015), pp. 43-54. 
while reducing its support for foreign communist parties. With the onset of Deng Xiaoping's reforms, the claim that Beijing was supporting the overseas Chinese became less plausible. As we will see, Malaysia was quick to adjust its perceptions to the realities of the post-Cold War era and embraced better relations with China. In Indonesia, however, it took the demise of Suharto in 1998 until Jakarta finally acknowledged that the era of Chinese interference was over.

Once they had adjusted to the new realities, both countries were able to base their relations with China on shared interests while dealing with any differences, such as territorial disputes in the South China Sea, without fear that China might play the ethnic card. Since Beijing has largely abandoned the ethnic Chinese to their host societies, real or perceived intermestic challenges have ceased to overshadow Sino-Malaysian and Sino-Indonesian relations.

\section{Malaysia}

In Malaysia, $24.6 \%$ of the population are ethnic Chinese. ${ }^{75}$ Much of the economy has been-and still is — run by Chinese businesses and labor, despite affirmative action to increase the wealth of the indigenous population, which is mostly composed of Malay Muslims. This has led to mutual grievances, with the Malay majority resenting Chinese economic success and the Chinese minority perceiving pro-Malay policies as a gross injustice and violation of meritocracy.

\footnotetext{
${ }^{75}$ Department of Statistics Malaysia, Population and Housing Census of Malaysia; see also Eng and Peng, 'Demographic processes and changes.'
} 
Especially after serious anti-Chinese riots in 1969, Malaysia aggressively empowered indigenous Malay (bumiputera) businesses and labor at the expense of the ethnic Chinese. Sino-Malaysian trade was partly taken over by bumiputera elites. ${ }^{76}$ Malaysia’s longstanding leader, Mahathir Mohamad, had the declared objective of 'improving the economic status of the Malay community, and enlarging the overall economic pie for the benefit of the non-Malay races. ${ }^{77}$

Since Deng Xiaoping’s reforms, China has stopped supporting the ethnic Chinese and accepted that the way Malaysia treats them is a domestic issue. A communist radio station operating from Yunnan closed in 1981. The insurgency by the Communist Party of Malaysia ended in December 1989, when the party finally disbanded after a peace agreement. ${ }^{78}$ Due to Beijing's willingness to stop supporting the ethnic Chinese, Sino-Malaysian relations improved considerably. Mahathir Mohamad even saw China as an ally in his anti-western agenda of reducing US influence. ${ }^{79}$

While allowing Beijing to improve its relations with Kuala Lumpur, the new policy failed to address the plight of Malaysia's ethnic Chinese who continue to suffer from explicit and deliberate

${ }^{76}$ Kua Kia Soong, May 13: Declassified Documents on the Malaysian Riots of 1969 (Selangor: Suaram, 2007).

77 Joseph Chinyong Liow, 'Malaysia-China relations in the 1990s: the maturing of a partnership,' Asian Survey 40:4 (2000), pp. 672-691, at 675-676.

${ }^{78}$ Ong Weichong, Malaysia's Defeat of Armed Communism: The Second Emergency, 1968-1989 (London: Routledge, 2015).

${ }^{79}$ Joseph Chinyong Liow, 'Malaysia’s post-cold war China policy: a reassessment,' in The Rise of China: Responses from Southeast Asia and Japan, ed. Jun Tsunekawa (Tokyo: National Institute for Defence Studies, 2009), pp. 47-79. 
discrimination (the flipside of affirmative action in support of the indigenous Malay, which has been enshrined in the constitution). ${ }^{80}$ Malaysia's ethnic Chinese suffer from discrimination not only in the marketplace but also at the communal and bureaucratic level. For example, the life of Chinese pig farmers is made difficult by Muslim neighbors and Malaysian authorities. ${ }^{81}$

This is not to claim that Malaysia's ethnic Chinese are powerless. The ruling coalition depends on their vote and, for example, had to back down on a controversial apostasy law. ${ }^{82}$ However, despite official lip-service to race equality, Malaysia’s central identity remains that of the bumiputera 'sons of the soil,' which are mostly Malay Muslims. Ethnic Chinese, as well as Indians, are per definition excluded from this central identity. ${ }^{83}$ Some of the latter have a strong urge to transcend such fixed categories, but this remains at best a distant dream. ${ }^{84}$

\footnotetext{
${ }^{80}$ Hwok-Aun Lee, Edmund Terence Gomez, and Shakila Yacob, 'Ethnicity, economy, and affirmative action in Malaysia,' in Affirmative Action, Ethnicity, and Conflict, ed. Edmung Terence Gomez and Ralph Premdas (London: Routledge, 2013), pp. 67-94.

${ }^{81}$ Harvey Neo, ““They hate pigs, Chinese farmers...everything!”: beastly racialization in multethnic Malaysia,' Antipode 44:3 (2012), pp. 950-970.

${ }^{82}$ Kikue Hamayotsu, 'Once a Muslim, always a Muslim: the politics of state enforcement of Shariah in contemporary Malaysia,' South East Asia Research 20:3 (2012), pp. 399-421.

${ }^{83}$ Eugene K.B. Tan, 'From sojourners to citizens: managing the ethnic Chinese minority in Indonesia and Malaysia,' Ethnic and Racial Studies 24:6 (2001), pp. 949-978.

${ }^{84}$ Sharmani P. Gabriel, 'The meaning of race in Malaysia: colonial, post-colonial and possible new conjunctures,' Ethnicities 15:6 (2015), pp. 782-809.
} 
While race relations in Malaysia remain complicated, and while many indigenous Malays continue to resent the economic strength of the Chinese community, three decades after the end of the Cold War few Malaysians would argue that the transnational bonds of the ethnic Chinese with their ancestral homeland pose a significant intermestic security challenge.

\section{Indonesia}

Like in Malaysia, the Chinese business diaspora in Indonesia concentrates enormous wealth. Also like in Malaysia, the indigenous majority resents the concentration of wealth in Chinese hands. ${ }^{85}$ Again like in Malaysia, indigenous Indonesians sometimes regard the ethnic Chinese as disloyal citizens. When President Suharto came to power after an abortive coup in 1965, he blamed ethnic Chinese in general, and the Communist Party in particular, for the turmoil. Countless ethnic Chinese died in the subsequent bloodbaths. Beijing reacted by repatriating thousands of ethnic Chinese. Jakarta, in turn, suspended diplomatic relations with Beijing. ${ }^{86}$

It took 23 years, from 1967 to 1990, until the two countries finally resumed diplomatic relations. Even then, at a time when Malaysia was already warming up to China, Indonesia stuck to the China threat thesis. In line with public discourse depicting the ethnic Chinese as reckless businesspeople and disloyal citizens, anti-Chinese riots broke out in Medan, Sumatra, in April 1994.

\footnotetext{
${ }^{85}$ With 1.2 percent, the share of ethnic Chinese in Indonesia is much smaller than in Malaysia. See Arifin, Hasbullah, and Pramono, 'Chinese Indonesians.'

${ }^{86}$ Rizal Sukma, Indonesia and China: The Politics of a Troubled Relationship (London: Routledge, 1999).
} 
When Beijing expressed concerns, Jakarta bemoaned foreign interference. As the Indonesian government hastened to declare, 'China had better mind its own internal affairs. ${ }^{\text {,87 }}$

In 1998, even more serious anti-Chinese pogroms occurred on Sumatra and Java. They coincided with a political situation when the Asian Financial Crisis was precipitating Suharto's demise. Although the exact course of events remains somewhat unclear, it seems that elements of Suharto's fledgling New Order regime, in an effort to exploit a combination of populist resentment and Islamist agendas, conducted a campaign of publicly denouncing the ethnic Chinese. The campaign culminated in the infamous May riots in Jakarta, when Chinese shops were burnt and looted, and more than 1,000 people lost their lives. Scores of ethnic Chinese fled from the archipelago, and significant Chinese investment left the country. This was particularly damaging given the fact that Indonesia was already suffering from the fallout of the financial crisis. ${ }^{88}$

The stage seemed set for another round of declarations of concern from Beijing, followed by vitriolic rebuttals from Jakarta. This time, however, nothing of that sort happened. Even when more than a hundred Chinese women had been raped in Jakarta, leading to strong expressions of outrage and solidarity among ethnic Chinese across the region, it took Beijing more than two

\footnotetext{
${ }^{87}$ Rizal Sukma, 'Indonesia-China relations: the politics of re-engagement,' Asian Survey 49:4 (2009), pp. 591-608, at 594.

${ }^{88}$ John T. Sidel, Riots, Pogroms, Jihad: Religious Violence in Indonesia (Ithaca, NY: Cornell University Press, 2006); Jemma Purdey, Anti-Chinese Violence in Indonesia, 1996-1999

(Honolulu: University of Hawaii Press, 2006).
} 
months to express any concern. ${ }^{89}$ When it finally did, Beijing used euphemistic and reconciliatory language, calling the incidents a 'misfortune' and labelling the victims as 'Indonesians of Chinese descent' (yinni huaren) rather than overseas Chinese (huaqiao). In the words of China's ambassador, the predicament of Indonesia’s ethnic Chinese was ‘part of Indonesia’s domestic politics. Its resolution must come from the Indonesian government itself. The Chinese government must not act as if it could be the chef in somebody else's kitchen.90

It seems that, had it not been for the mobilization of ethnic Chinese all over the world as well as nationalist rallies by university students in China, even this muted response would not have been forthcoming. Beijing did not do anything that might have jeopardized its diplomatic ties with Jakarta, and continued its economic relief for Indonesia's crisis-stricken economy. To reassure Indonesian leaders and the public, President Jiang Zemin made clear that China would 'never try to use people of Chinese origin living in Indonesia to seek political or economic gain there. ${ }^{91}$

Thus, paradoxically, it took the Jakarta riots for Indonesia to overcome the Cold War legacy of mistrusting China. By its inaction in 1998, Beijing had finally signaled persuasively that it was a 'responsible’ power rather than trying to interfere in Indonesia’s domestic affairs by supporting the country’s ethnic Chinese. What is more, unlike Suharto’s ancien régime, Indonesia’s new democratic government did not need the China threat thesis to bolster its legitimacy.

\footnotetext{
${ }^{89}$ Purdey, Anti-Chinese Violence in Indonesia, pp. 165-168.

${ }^{90}$ Daojiong Zha, 'China and the May 1998 riots of Indonesia: exploring the issues,' Pacific Review 13:4 (2000), pp. 557-575, at 564.

${ }^{91}$ Ibid., p. 563.
} 
This is not to say that anti-Chinese sentiment in Indonesia has completely evaporated. Indonesian perceptions 'continue to be colored by various stereotypes associated with the ethnic Chinese minority. ${ }^{92}$ Indigenous (pribumi) Indonesians continue to resent the fact that businesspeople from the PRC sometimes prefer to deal with their ethnic kin. Nevertheless, anti-Chinese resentment in the post-Suharto era has mellowed compared to the previous regime, and to some extent this has enabled the ethnic Chinese to reinvent their identity as Indonesian citizens. ${ }^{93}$

Although after a considerable time lag compared to Malaysia, the perception of an intermestic challenge has ceased to play any discernible role in Sino-Indonesian relations. Contentious issues such as maritime disputes in the South China Sea are dealt with at the diplomatic level, with occasional outbursts of nationalist passion and military swaggering. No matter how serious the crisis, Beijing never tries to use Southeast Asia’s ethnic Chinese as a proxy. Beijing kept silent when the ethnic Chinese governor of Jakarta, Basuki Tjahaja Purnama, faced an ugly blasphemy campaign leaving the Chinese minority feeling 'unsafe.' ${ }^{94}$ Nor does China intervene when ethnic Chinese suffer from other forms of discrimination at the hands of their host society.

\footnotetext{
92 Sukma, 'Indonesia-China relations,' p. 605.

${ }^{93}$ Chang-Yau Hoon, 'Assimilation, multiculturalism, hybridity: the dilemmas of the ethnic Chinese in post-Suharto Indonesia,' Asian Ethnicity 7:2 (2006), pp. 149-166; Sarah Turner and Pamela Allen, 'Chinese Indonesians in a rapidly changing nation: pressures of ethnicity and identity,' Asia Pacific Viewpoint 48:1 (2007), pp. 112-127.

${ }^{94}$ Ben Bland, 'Jakarta election battle reignites debate over Islam and the state,’ Financial Times, 20 February 2017.
} 


\section{Conclusion}

Intermestic security challenges arise when there is concern in a country that a dissatisfied minority relies on transnational bonds with a foreign kin-group for support. Such challenges occur when ethnic and/or ideological affinities translate into foreign support seen as problematic. They are aggravated when the dissatisfied minority is able to raise territorial claims.

The good news emerging from this article is that intermestic challenges can be managed. The bad news is that, if they are not managed well, they can escalate into civil wars and other political calamities. Examples abound, from ethnic bonds contributing to the Balkan wars of the 1990s to the ongoing 'sectarianization' of the Middle East. ${ }^{95}$ Especially in the so-called 'Shia Crescent' spanning from Iran to Libya and from Yemen to Bahrain, sectarianism appears more salient than ethnic bonds. ${ }^{96}$ Elsewhere, ethnic bonds continue to play a predominant role: Russians in Ukraine; Kurds in Syria and Iraq; Tamils in Sri Lanka. ${ }^{97}$ All of these ethnic and/or ideological bonds pose intermestic security challenges that have ushered in serious political mayhem.

${ }^{95}$ Ivanka Nedeva Atanasova, 'Transborder ethnic minorities and their impact on the security of Southeastern Europe,’ Nationalities Papers 32:2 (2004), pp. 355-442; Hashemi and Postel, Sectarianization.

${ }^{96}$ Nasr, The Shia Revival.

${ }^{97}$ Winslett, 'Differential threat perceptions’ (on the Kurdish question); Amali Wedagedara, 'The “ethnic question” in India-Sri Lanka relations in the post-LTTE phase,' Strategic Analysis 37:1 (2013), pp. 65-83. 
In the cases examined, China has managed significant intermestic challenges in pragmatic and nuanced ways. The case of the ethnic Chinese was perhaps a bit less challenging because Beijing had agency as the real or perceived originator of foreign support. What is more, the ethnic Chinese were never in a position to raise territorial claims. The demise of communism has enabled China to stop posing, and China's Southeast Asian neighbors to stop perceiving an intermestic challenge, leading to improved diplomatic relations. Beijing has ended its former policy of patronizing the ethnic Chinese, and is reaping the benefits of better diplomatic relations.

In the Uyghur case, the rise of political Islam as a transnational ideology and the opening of China's borders after the 1978 reforms have exacerbated the claims of ethno-nationalist Uyghur for Xinjiang as their homeland and/or as an Islamic entity. This territorial dimension has made the intermestic challenge posed by the Uyghurs more serious for Beijing. At the same time, China is at the receiving end of the challenge and hence its agency is somewhat constrained. Nevertheless, Beijing has taken a broad range of political measures to contain the unintended effects of intensified cross-border commerce. The approach ranges from domestic and unilateral to bilateral, as with Pakistan, and multilateral, as in the Shanghai Cooperation Organization.

Even though Beijing has been relatively successful in managing either challenge, there are limits to what its policies are able to accomplish. Despite Beijing's efforts, unwelcome religious influence continues to emanate from Muslim-majority countries and contributes to the radicalization of Uyghurs. What is more, China's repressive and authoritarian approach sometimes leads to a backlash. In Malaysia and Indonesia, China is impotent in the face of discrimination against ethnic Chinese as an official policy (Malaysia) and at the popular level (both countries). It is hard 
for Beijing to turn the clock back and speak up on behalf of ethnic Chinese. In the rare instances when this happens, it triggers angry reactions that make it politically rather costly. ${ }^{98}$

\section{Where to go from here}

Despite the limits to what China has been able to accomplish, the achievement of managing two difficult intermestic security challenges is remarkable. It is worth asking to what extent other countries might be able to replicate the management strategies adopted by China.

In fact, other countries already adopt similar strategies, albeit short of deliberate imitation. Turkey’s post-Cold War abstention from supporting ethnic Turks in Bulgaria bears resemblance to China's post-Cold War abstention from supporting ethnic Chinese in Southeast Asia. ${ }^{99}$ Thus far, Ankara's abstention from supporting Turks in Bulgaria compares favorably with Albania’s failure to display similar abstention from supporting co-ethnics in 'greater Albania.'100

Reformers in Iran who are interested in better relations with other countries, and especially with Sunni-dominated countries, might take a page from this playbook. A first step would be to stop

\footnotetext{
98 ‘China defends envoy to Malaysia after comments on racism,’ Reuters, 28 September 2015.

${ }^{99}$ Benedict E. DeDominicis, 'The Bulgarian ethnic model: post-1989 Bulgarian ethnic conflic resolution,’ Nationalities Papers 39:3 (2011), pp. 441-460.

${ }^{100}$ Maria Koinova, 'Kinstate intervention in ethnic conflicts: Albania and Turkey compared,' Ethnopolitics 7:4 (2008), pp. 373-390. Turkish restraint has recently come under stress. See 'Erdogan says Bulgaria’s pressure on Turks “unacceptable,”’ Reuters, 23 March 2017.
} 
supporting Shiite and other sectarian groups in foreign countries, just like Beijing did with regard to foreign communist parties dominated by ethnic Chinese. The next step would be for Tehran to make this policy shift irreversible and to communicate it in unambiguous terms. Taking Indonesia's tardy response to the Chinese policy change as an indicator, some of Iran's neighboring countries might take their time to register the change and stop antagonizing Tehran. All the more, Tehran would have to declare its restraint publicly, convincingly, and repeatedly.

China's collaboration with its Central and South Asian neighboring countries in containing the Uyghurs is an even harder act to follow. For obvious reasons, liberal countries may not be willing or able to go down that route. However, less liberal countries may be so inclined and, as in the case of the ethnic Chinese, there are already historical precedents for this. Initially, the Gulf Cooperation Council was a response to the Iranian revolution of 1979. More recently, Saudi Arabia has allegedly been trying to cobble together an anti-Shia Islamic Alliance. ${ }^{101}$ There are obvious parallels between these regional projects and the Shanghai Cooperation Organization.

The 'west' may also have its lessons to learn. Recent policies such as President Trump's ‘travel ban’ against visitors from certain Muslim countries betray a focus on nationality rather than ideology. While there is nothing wrong with the idea of migration control and while it would be rather impractical to sort migrants based on their ideological orientation, an ethnic focus may turn out counterproductive. The analysis of antecedent conditions suggests that the ideological element is more important than the ethnic element of intermestic challenges, and the case studies confirm that operating on the ideological element is more productive. If this is so, then the west

\footnotetext{
${ }^{101}$ Salman Masood and Ben Hubbard, 'Pakistan approves military hero to head tricky Saudi-led alliance,’ New York Times, 3 April 2017.
} 
should focus on Islamism rather than, say, Middle Eastern ethnicity. It plays into the hand of Islamists when they can present western policies as ethnically motivated or even racist. Politicians must strive hard to explain that, far from this, their policies are moves in a battle of ideas.

While there is legitimate disagreement as to what might be admissible on normative grounds, this article has shown that intermestic security challenges can be managed. Future research will add nuance and uncover further management strategies. In the meantime, the theoretical model developed and the strategies discussed may turn out useful in many other settings, from the ‘Kurdish question’ via the ‘Shia crescent’ to transnational Islamism in Western Europe. 